\title{
Mitä on kunnallinen aikuiskoulutus?
}

Kirjoitin Aikuiskasvatus-lehteen 1/82 artikkelin Vapaasta kansansivistystyöstä kunnalliseen aikuiskoulutukseen. ${ }^{1}$ Väitin siinä, että suurin vaara, joka vapaata sivistystyötä tällä hetkellä uhkaa, on hieman pisteliäästi sanottuna vapaan sivistystyön muuttaminen "'kunnalliseksi aikuiskoulutukseksi", toisin sanoen vapaan sivistystyön vapauden kaventaminen.

Nyt kunnallisen aikuiskoulutuksen toimikunta on jättänyt mietintönsä. ${ }^{2}$ On tullut tilaisuus katsoa, kuinka pahasti arvioni meni metsään.

\section{Yleistä}

Tarkastelen mietintöä vain kansalais- ja työväenopistojen osalta. Olen harvoin, jos koskaan saanut luettavakseni niin sekavaa esitystä kuin kunnallisen aikuiskoulutuksen toimikunnan mietintö on. Ensinnäkin mietintö hajoaa kolmeen osaan, joilla ei ole paljoakaan tekemistä toistensa kanssa (murtumakohdat ovat kappaleissa 3.1.2. ja 3.3.) Alkuosan yleisestä tilannearviosta ja johtopäätöksistä ei seuraa mitään, kun siirrytään tarkastelemaan kuntatason aikuiskoulutuksen tavoitteita ja konkreettista kehittämistä. Kaikki aloitetaan ikään kuin alusta ja kokonaan muista lähtökohdista kuin alun yleisessä osassa. Toiseksi mietinnöissä on useita päällekkäisiä jaksoja, joissa käsitellään samoja asioita (esim. hallinto, valtionosuusjärjestelmä). Päällekkäinen käsittely ei vielä olisi kovin vakavaa, mutta kun samasta asiasta esitetään toisistaan poikkeavia kannanottoja, on tilanne jo ongelmallinen (esim. valtionosuusjärjestelmä). Mietintöä vaivaakin siis kolmanneksi sisäinen ristiriitaisuus. Neljänneksi haluan kritikoida analyysin pinnallisuutta. Toimikunnan analyysin keskeinen metodi on asian jakaminen kahteen, kuten myöhemmin tulemme huomaamaan.

Vaikka osa sekavuudesta voidaan lukea esitystavan ongelmiksi, niin valitettavasti lukija ei voi välttyä ajatukselta, että epäselvä esitystapa kertoo myös jostakin perustavammasta - siitä että itse asiatkin on mietitty vain puolitiehen. Tämä on valitettavaa, koska tiedän hyvin, että toimikunnan tarkoitus on ollut parempi kuin se. mitä mietinnöstä voidaan lukea.

\section{Kunnallisen aikuis- koulutuksen käsite}

Monet mietinnön ongelmista johtuvat toimikunnan toimeksiannosta. Erityisesti tällöin on kysymys käsitteistä kunnallinen aikuiskoulutus ja muu kunnan tasolla tapahtuva aikuiskoulutus. Toimikunta on lähtenyt siitä, että se käyttää näitä käsitteitä pelkästään hallinnollisina käsitteinä. Tätä ratkaisua toimikunta perustelee kahdella seikalla. Ensinnäkin kyseisille käsitteille ei ole olemassa yksiselitteistä määritelmää suhteessa sivistystyön monivivahteiseen käytäntöön tai eri teorioihin. Toinen syy on, että kunnallisella tai kunnan tasolla tapahtuvalla aikuiskoulutuksella viitataan kuntaan. Kunta taas on ensisijaisesti hallinnollinen yksikkö, jollaisena se ei ole esimerkiksi aikuiskoulutuksen pedagogisten ratkaisujen tai sisällöllisten suuntaviivojen kehittelijä. (s. 1-2).

Kun toimikunta puhuu kunnallisesta aikuiskoulutuksesta, tarkoitetaan, että kyseinen toiminto liittyy kunnan hallintoon. Kun taas puhutaan muusta kunnan tasolla tapahtuvasta aikuiskoulutuksesta, tarkoitetaan toimintoa, joka ei liity kunnan hallintoon, joskin kunta voi esimerkiksi tukea sitä. Mutta tämäkään jako ei päde kaikkiin tapauksiin. Toimikunta kiinnittää huomionsa siihen, että jossain tapauksissa täysin rinnasteiset aikuiskoulutuksen muodot (esim. kunnalliset vs. yksityiset kansalaisopistot) jakautuvat tällä tavalla eri ryhmiin. Niinpä toimikunta on päätynyt käyttämään kuntatason aikuiskoulutuksen käsitettä, joka sisältää sekä kunnallisen aikuiskoulutuksen että muun kuntatasolla tapahtuvan aikuiskoulutuksen. (s. 3)

Mitä kuntatason aikuiskoulutukseen sitten luetaan kuuluvaksi? Siihen sisältyvät toimikunnan mukaan:

1) kansalais- ja työväenopistot

2) iltakoulut

3) kuntien henkilöstökoulutus

4) kuntatason ammatillinen aikuiskoulutus (ammatilliset kurssikeskukset, ammattioppilaitosten lisäkoulutus ja ilta-ammattikoulut). 
Rajatessaan aikuiskoulutuksen käsitteet pelkästään hallinnollisiksi käsitteiksi on toimikunta menetellyt mielestäni kaukoviisaasti. Näin toimikunta on välttänyt sellaisen määritelmän, josta olisi todennäköisesti ollut enemmän haittaa kuin hyötyä.

Toinen asia sitten on, että näiden hyvin erilaisten koulutusmuotojen kesken on syntynyt ja syntyy erilaisia käytännöllisiä työnjako- ja yhteistyöhankkeita, joita voidaan ratkaista kuntakohtaisesti. Ja tässä työssä esiintyy myös ongelmia. Kuntatason käytännön ongelmien pohtiminen toimikunnassa olisi vaatinut edustavaa kartoitusta aikuiskoulutuksen tilasta erilaisissa kunnissa. Tällaista kartoitusta ei vielä. ole, joten toimikunta oli asetettu mahdottoman tehtävän eteen.

Jos toimikunta tältä osin päätyikin "'nahkapäätökseen', ei vika ollut toimikunnan, vaan toimeksiannon. Ei voi kuin ihmetellä sellaista koulutussuunnittelua, jossa tämä merkitykseltään suurin vapaan sivistystyön toimintamuoto on niputettu yhteen mitä erilaisimpien koulutusmuotojen kanssa, kun sen sijaan kansanopistojen ja järjestöllisen sivistystyön ongelmia sentään voitiin ratkoa omissa toimikunnissa. Kun vertailee näiden toimikuntien aikaansaannoksia, voi vakuuttua, että tämän "sillisalaattitoimikunnan" eri osat ovat kaikki kärsineet tästä yhteenniputtamisesta niin sillit kuin salaatitkin.

Mitä siis on kunnallinen aikuiskoulutus? Tästä me emme edelleenkään tiedä sen enempää kuin ennen kunnallisen aikuiskoulutuksen toimikunnan mietinnön ilmestymistä - onneksi. Vastaus tähän kysymykseen jää annettavaksi siinä selvitystyössä, joka kunnissa on jo lähtenyt käyntiin - onneksi.

\section{Kuntatason aikuis- koulutuksen kehitys}

Korostaakseen kansalaisopiston, iltakoulujen ja kuntien henkilöstökoulutuksen erilaisuutta toimikunta käy läpi niiden kehitystä kunkin osalta erikseen. Sen sijaan ammatillista aikuiskoulutusta ja muita sivistys- ja kulttuuritoimintoja toimikunta tarkastelee yhteenkootusti. Käyn läpi vain kansalaisopistojen osuutta.

\subsection{Yhteiskunnallinen muutos}

Voimakkaasti yleistävä yhteiskunnallisen muutoksen kuvaus perustuu pääosin aikaisempiin selvityksiin ja valtakunnallisiin tilastoihin. Jos toimikunnan mietintöön tältä osin jotakin muuta sisältyy, niin se löytyy niistä jaksoista, joissa kuvataan viimeisen kymmenen vuoden kehitystä, siis aikaa aikuiskoulutuskomitean jälkeen. Ainakaan minä en näe erityistä syytä kritikoida toimikunnan kuvausta kansalais- ja työväenopistojen kehityksestä tältä osin.

Sen sijaan tähän jaksoon sisältyy eräitä sellaisia johtopäätöksiä yhteiskunnallisen muutoksen ja kansalaisopistojen kehityssuhteista joita minä en olisi uskaltanut tehdä toimikunnan esittämillä perusteilla. Tällainen on esim. johtopäätös kaupunki- ja maaseutuopistojen uudenlaisesta eriytymisestä. Toimikunnan mielestä opiskelijoiden sosiaalisella taustalla ei enää ole samanlaista merkitystä kuin aikaisemmin, vaan erot kaupunki- ja maaseutuopistojen opetusohjelmissa ja toimintatavoissa selittyvät itsestään (s. 17). Sitä toimikunta ei tarkemmin selitä, miksi kaupunkilaiset haluavat opiskella kieliä ja maalaiset kädentaitoja. Juuri tämä olisi ollut kiinnostavaa kulla, jos kerta opiskelijoiden sosiaalinen tausta on menettänyt selitysvoimansa.

Kuntatason ongelmiin toimikunta ei pääse juuri lainkaan kiinni, koska sillä ei ole tähän tarkoitukseen sopivia aineistoja. Itse asiassa yhteiskunnallista muutosta kuvaavien muuttujien joukosta puuttuu kunta omana muuttujanaan. Tietenkin esim. elinkeinorakenne, yhdyskuntarakenne ja koulutustaso liittyvät myös kuntien kehitykseen, mutta aikuiskoulutuksen kannalta kunta sisältää paljon muutakin (esim. perinteet, oppilaitosrakenne, sijainti jne.). Tästä kuntatason katoamisesta tarkastelusta seuraa eräs vakava ongelma, johon palaan kun arvioin toimikunnan tavoiteproblematiikkaa.

\subsection{Sivistykselliset ja pedagogiset pyrkimykset}

Jaksoon, jossa toimikunta tarkastelee kuntatason aikuiskoulutukseen liittyviä sivistyksellisiä pyrkimyksiä, voin yhtyä. Juuri tämä osuus osoittaa selvästi, kuinka erilaisista toiminnoista kuntatason aikuiskoulutuksessa on kysymys ja kuinka keinotekoista näiden toimintojen paketoiminen yhteen on.

Pedagogisia pyrkimyksiä käsittelevään kappaleeseen (2.3.3.) sisältyy jälleen johtopäätös, jota sietäisi tutkia tarkemmin. Toimikunnan mukaan 1960- ja 1970-luvuilla tapahtui murtuma, jossa perinteinen kutsumustyötä tekevä "sivistyspersoona"' sai väistyä. Tilalle astuivat ammatillisesti suuntautuneet kouluttajat. Tämän seurauksena historiallisen sivistysajatuksen vaikutus aikuiskoulutukseen lähes katkesi. Toimikunnan mukaan tämä heijastui myös käytännön pedagogisiin ratkaisuihin. 
Ainakaan Alasen (19803) kirjoituksesta "'Aikuiskasvattajan ammatti: kehityssuuntia ja ongelmia" ei saa vahvistusta näin radikaalille johtopäätökselle, vaikka ammatillisesti suuntautuneet teknokraatit ovatkin varmasti vallanneet asemia varsinkin ammatillisen aikuiskoulutuksen puolella. Mutta kuinka hyvin tämä on yleistettävissä vapaaseen sivistystyöhön on jo toinen asia, jota ei vielä voi päätellä joidenkin tunnettujen sivistyspersoonien poistumisesta vapaan sivistystyön kentältä.

Sama koskee mielestäni sitä toimikunnan arviota uudesta kehitysvaiheesta, joka kiteytyisi kognitiivisen oppimisteorian ja yhteisökasvatuksen esiinmarssiin (s. 32). Ainakaan minä en ole vielä havainnut mitään radikaalia toimintatapojen muutosta opistoissa, vaikka asiasta onkin puhuttu.

\subsection{Hallinnollinen kehitys}

Kuntatason aikuiskoulutuksen hallinnollisen kehityksen toimikunta käy läpi erikseen eri koulutusmuotojen osalta, eikä tuo esiin mitään uutta. Voi jopa sanoa, että toimikunta ei kirjaa edes kaikkea sitä, mikä on jo tiedossa. Tarkoitan tällä sitä kehitystä, jota on kuvattu valtiollisen säätelyn käsitteellä. Olisi ollut mielenkiintoista tietää, minkälaisen painon toimikunta antaa tälle kehityspiirteelle. Pelkkä viittaus valtionosuusjärjestelmän kautta tapahtuvaan valtiolliseen ohjailuun (s. 38) ei kata tätä hyvin monitahoista kysymystä.

\section{Tarveproblematiikka}

\subsection{Tarpeet yleensä}

Toimikunta jakaa kuntatason aikuiskoulutuksen kehittämisehdotukset kolmeen pääryhmään: kehittämisen pääsuuntaviivoihin, organisaation ja hallinnon kehittämiseen sekä lainsäädännöllisiin uudistuksiin (s. 41). Kehittämisen lähtökohtia miettiessään toimikunta on törmännyt toimeksiannon vaatimukseen selvittää vastaavuus aikuisten koulutustarpeiden ja nykyisen kuntatason aikuiskoulutuksen välillä. Toimikunta on yrittänyt saada otetta tästä tehtävästä jakamalla tarveproblematiikan kahtia: ensinnäkin yleiseen tarveproblematiikkaan mukaanlukien arvokysymykset ja toiseksi kuntatason aikuiskoulutukseen liittyviin tarpeisiin sellaisina kuin ne ilmenevät käytännössä (s. 42).
Yleistä tarveproblematiikkaa on toimikunnan mielestä mahdollista lähestyä jälleen kahdesta näkökulmasta: toisaalta ihmisen kannalta, toisaalta sivilisaation kannalta (s. 42). Vastaavasti tarpeet jakautuvat yleisellä tasolla kahteen ryhmään: ihmissidonnaisiin tarpeisiin (elämisen välineet, työ) ja sivilisaatiosidonnaisiin tarpeisiin (s. 42-43).

Tämän jälkeen toimikunta pohtii yleisesti näiden tarpeiden tyydytyksen muotoja ja päätyy siihen johtopäätökseen, että koulutuspolitiikan merkitys on ratkaisevasti kasvanut sivilisaation ylläpitämisessä (s. 44). Koska tämä johtopäätös on entuudestaan tuttu, on mielenkiintoisempaa katsoa, mitä tästä seuraa kuntatason aikuiskoulutuksen kannalta. 'Kuntatason aikuiskoulutuksen kannalta on olennaista, miten sen muodot liittyvät sivilisaatiosidonnaisiin tarpeisiin ja miten nämä tarpeet ilmenevät koulutus- ja muussa yhteiskuntapolitiikassa. Tällaisten kysymysten osalta ei kuitenkaan sikäli ole olemassa mitään yksiselitteisiä vastauksia, koska tätä kautta joudutaan ottamaan kantaa yhteiskuntapolitiikan suuntaan koskeviin kysymyksiin."' (s. 45).

Ei siis seurannut mitään. Tämän johdatuksen jälkeen toimikunta siirtyy tarkastelemaan sivistystarpeiden käytännön toteutumista kuntatason aikuiskoulutuksessa.

\subsection{Tarpeet kuntatason aikuiskoulutuksessa}

Kuntatason aikuiskoulutukseen liittyvät tarpeet kanavoituvat toimikunnan mielestä kahta kautta jo tutuksi tullutta kaavaa noudattaen: toisaalta kuntalaisten ilmaisemina ihmissidonnaisina tarpeina ja toisaalta koulutuspolitiikan ja muun yhteiskuntapolitiikan kautta ilmaistuina sivilisaatiosidonnaisina tarpeina (s. 45). Yllä olevaa sitaattia ei siis pidä tulkita niin, etteikö kuntatason aikuiskoulutuksessa jouduttaisi tekemisiin myös ihmissidonnaisten tarpeiden kanssa.

Kun tarpeita aletaan tyydyttää kuntatason aikuiskoulutuksessa, ottaa toimikunta periaatteelliseksi lähtökohdakseen koulutuksellisen tasa-arvon vaatimuksen, johon sisältyy kaksi ulottuvuutta. Ensimmäinen on oikeus saada tyydyttää koulutustarpeet (toimikunnan luokituksessa ihmissidonnainen tarve), toinen mahdollisuuksien luominen näiden tarpeiden tyydyttämiselle (toimikunnan luokituksessa sivilisaatiosidonnainen tarve) (s. 45-46). Ja nyt seuraa kannanotto, jonka toteuttamisessa 
riittää purtavaa pitkäksi aikaa: '’Koulutus- ja yhteiskuntapolitiikan keinoin on kyettävä vastaamaan kaikkiin kuntatasolla ilmeneviin aikuisten koulutustarpeisiin"' (s. 46).

Anteeksi vain arvon toimikunta, mutta minun mielestäni tämä kannanotto on järjetön. Ymmärrän kyllä, että tarkoituksenne on ollut hyvä. Mutta olen sitä mieltä, että esim. Urpo Harvan näkemys koulutuksellisesta tasa-arvosta on paljon syvällisempi kuin teidän. Hänen mielestään kohtuullinen pyrkimys esim. oppimisvaikeuksien voittamiseen ja huono-osaisten auttamiseen on mielekästä, kun otetaan huomioon rajalliset resurssit (ks. Harva 1982). ${ }^{4}$

Tämän jälkeen seuraa mietinnössä jakso, jossa toimikunta yrittää selvittää koulutustarpeita kuntatasolla nojautumalla valtakunnallisiin koulutustilastoihin. On selvää, ettei toimikunnan tarkastelu näistä lähtökohdista voi mitenkään olennaisesti poiketa esim. aikuiskoulutuskomitean noin 10 vuotta sitten suorittamasta tarkastelusta.

Yhteenvedossaan tarveproblematiikasta toimikunta asettaa uudestaan vaatimuksen, että kaikki koulutustarpeet tyydytetään. Keskeiset ongelmat nykytilanteessa löytyvät osallistumista koskevista tiedoista. Päinvastoin kuin aikaisemmin (s. 17) toimikunta pitääkin yhä edelleen sosiaalisia seikkoja, erityisesti pohjakoulutusta, merkittävinä vaikuttajina aikuiskoulutukseen osallistumisessa (s. 58). Myöskin alueellisesti on eroja. Kaupungissa on enemmän opiskelumahdollisuuksia kuin muualla. Tämä koskee erityisesti tutkintotavoitteista koulutusta. Naiset osallistuvat miehiä enemmän aikuisopiskeluun. Ikäkin vaikuttaa, joskaan ei niin paljon kuin ennen. Erityisesti ikä vaikuttaa siihen, mitä opiskellaan (s. 59). Nämä tiedot eivät uutuudellaan yllätä, mutta ilmeisesti ne ovat tosia, kun ne taas kerran on löydetty.

Yllättävää kuitenkin on se, että kaiken tämän jälkeen toimikunta ei aseta tarpeita minkäänlaiseen tärkeysjärjestykseen (vrt. aikuiskoulutuskomitea), vaan toteaa lopuksi täysin yhdentekevästi:

"1) kuntatason aikuiskoulutuksen tulee nykyistä paremmin kyetä tyydyttämään eri ryhmien erilaiset sivistystarpeet ja kehittelemään joustavasti erilaisia opiskelun muotoja;

2) kuntatason aikuiskoulutuksessa tulee nykyistä selvemmin ottaa huomioon sosiaalisista, sivistyksellisistä, alueellisista tai muista vastaavista syistä heikoimmassa asemassa olevien ryhmien opiskelumahdollisuudet"' (s. 60).
Mihin suuntaan resurssit konkreettisesti pitäisi tämän perusteella suunnata? Onko toimenpiteillä mitään kiireellisyysjärjestystä?

\section{Tavoiteproblematiikka}

Tässä jaksossa toimikunta tuo analyysiinsa jotakin uutta. Tämä uutuus on ns. skenariomenetelmä, jonka avulla asetetaan kuntatason aikuiskoulutuksen tavoitteet. Syynä menetelmän valintaan on ollut se, että perinteiset, nykyisestä tilanteesta lähtevät suunnittelumenetelmät ovat jäykkiä nopeasti muuttuvissa olosuhteissa. Tässä vaiheessa toimikunta siis irtoaa mitä perinteisimmistä nykytilaa kartoittamaan pyrkivästä koulutussuunnittelusta ja astuu kauas tulevaisuuteen.

Toimikunta on valinnut joukon tekijöitä, joita se pitää tärkeimpinä kuntatason aikuiskoulutuksen kehityksen kannalta. Kunkin osatekijän osalta toimikunta on määritellyt toisaalta nykyisen linjan jatkumisen seuraukset ja toisaalta toivottavat ja ei-toivottavat asiantilat. Tältä pohjalta on sitten voitu asettaa ne tavoitteet, joiden toimikunta ajattelee nykyisessä tilanteessa johtavan kohti toivottua asiantilaa.

Mitä sitten tuloksiksi saadaan? Otetaan esimerkki heti skenarion alusta, kohdasta kunnallisen demokratian toteutuminen: "Toimiva kunnallinen demokratia synnyttää kuntalaisissa osallistumisen edellyttämien tietojen ja taitojen hankkimisen tarvetta. Toisaalta yhteiskunnalliseen osallistumiseen liittyvien tietojen ja taitojen tarjoaminen lisää osaltaan kunnallisen demokratian toimivuutta. Toimikunta asettaa kuntatason aikuiskoulutuksen tavoitteeksi, että

- aikuiskoulutuksen suunnittelussa ja toteuttamisessa yhtenä lähtökohtana on demokratian toteutumiseen liittyvien tiedollisten, taidollisten ja asenteellisten valmiuksien luominen..."' (s. 61).

Analyysi jatkuu samanlaisena liirum laarumina kaikkien tekijöiden osalta. Lopputuloksena on ehtymätön toiveiden tynnyri, joka viitoittaa kivettömän tien ihanneyhteiskuntaan. Jos joku sattuisi kysymään, miten tämä kaikki voidaan toteuttaa käytännössä, vastaa toimikunta: "tavoitteiden toteutumisen edellytyksenä on, että kuntatason aikuiskoulutuksen muodoilla on käytettävissä riittävästi resursseja, jotka hyödynnetään optimaalisesti’' (s. 69). Yksinkertaista, peräti yksinkertaista on utopian rakentaminen. Miksiköhän sinne ei vielä ole päästy? 
Sanoin aikaisemmin, että toimikunnan analyysistä katosi kuntataso. Tästä seuraa vakava ongelma myös tavoiteasettelulle. Olemme nyt tämän ongelman äärellä. Toimikunnan tavoiteasettelulla ei ole mitään tekemistä esim. niiden taloudellisten realiteettien kanssa, jotka kunnissa ja valtion taloudessakin tätä nykyä vallitsevat. Emme myöskään mistään saa tietää, kuinka kaukana tai lähellä me olemme toimikunnan hahmottelemaa ihannetilaa. Pidän siis tätä jaksoa toimikunnan mietinnössä hyödyttömänä käytännön kehittämistoimenpiteiden kannalta.

\section{Yleiset kuntatason aikuis- koulutuksen kehittämis- toimenpiteet}

On tietenkin johdonmukaista, että jos toimikunnan tavoiteasettelu katosi jonnekin kauas tulevaisuuteen, niin yleisiä kehittämisehdotuksiakin vaivaa jääminen toivomusponsien tasolle. Niinpä toimikunta toivoo, että yhteiskuntapolitiikassa otetaan huomioon aikuiskoulutuksen kasvava merkitys ja sen muuttuminen yhdeksi avainalueeksi (s. 71). Edelleen toimikunta pitäisi hyvänä, että kuntatason aikuiskoulutukselle turvattaisiin kaikissa kunnissa vakaat toiminta- ja kehittämisedellytykset yhtenä kunnallisena peruspalveluna (s. 72). Suotavaa olisi toimikunnan mielestä, että kunnallisen aikuiskoulutuksen taloudelliset toimintaedellytykset turvattaisiin riittävinä siten, että kehittämissuunnitelmat voitaisiin toteuttaa kuntasuunnittelun edellyttämällä viiden vuoden aikavälillä (s. 73).

Hyviä toivomuksia toisensa perään, eikä yhtään ehdotusta siitä, miten ne käytännössä toteutetaan. KTOL:n tavoiteohjelmassakin päästään pitemmälle. Siellähän ehdotetaan vapaan sivistystyön puitelain säätämistä.

Vähän konkreettisemmaksi muuttuvat toimikunnan ehdotukset, kun aletaan miettiä kuntatason aikuiskoulutuksen eri muotojen välistä työnjakoa ja yhteistyötä. Lähtökohtana on tietenkin se, että tarvitaan yhteistyötä (s. 74). Varsin selvältä jo tuntuu toimikunnan ehdotus siitä, että iltakoulut vastaisivat ensisijaisesti aikuisten peruskoulun ja lukion opinnoista. Siellä, missä iltakouluja ei ole ja mihin niitä ei ole tarkoituksenmukaista perustaa, tämän opetuksen järjestämisestä vastaavat muut aikuisille soveltuvat oppilaitokset kuten kansalais- opistot (s. 75). Samoin konkreettinen on ehdotus siitä, että kehiteltäessä palkallista opintovapaata ja muita opintososiaalisia tukimuotoja tutkintotavoitteinen opiskelu rinnastetaan ammatilliseen aikuiskoulutukseen (s. 76).

\section{Kansalaisopistojen kehittämistoimenpiteet}

\subsection{Yleistä}

Toimikunnan mielestä kansalaisopistojen rooli maamme sivistystyön kentässä on suhteellisen selvä, joten se ei anna aihetta olennaisiin muutoksiin. Kansalaisopistojen luonne määräytyy siitä, että ne ovat "ensisijaisesti aikuisten vapaa-ajan sivistyslaitoksia, joiden tehtävänä on tyydyttää kansalaisten sivistystarpeita järjestämällä opetusta, joka edesauttaa kansalaisten omaehtoista henkistä itsensä kehittämistä sekä tarjoaa heille kansalaiselämässä tarvittavia tietoja ja taitoja"' (s. 78).

Tämä määritelmä tyydyttää ainakin minua pääosin, mutta kahdesta seikasta haluaisin virittää keskustelua. Määritelläänkö kansalaisopisto ensinnäkin sivistys- vaiko aikuisoppilaitokseksi? Ja toiseksi, puhutaanko yleensä kansalaisten itsensä kehittämisestä vai kansalaisten omaehtoisesta henkisestä itsensä kehittämisestä? Ensimmäisen kysymyksen osalta olen sillä kannalla, että kansalaisopistot pitäisi määritellä aikuisoppilaitoksiksi, koska se kuvaa tarkemmin, mistä opiston toiminnan perusluonne määräytyy. Opistossa opetetaan ja opiskellaan. Tietenkin opisto välittää sivistystä, mutta niin tekevät esim. kirjastotkin. Toisen kysymyksen osalta olen yleisemmän muotoilun kannalla, koska pidän arvokkaana esim. sitä opistoissa harjoitettavaa käden taitojen opetusta, jota ei välttämättä voida pitää henkisenä itsensä kehittämisenä.

Vaikka toimikunta haluaa säilyttää kansalaisopistot aikuisten sivistyslaitoksina, näkee se aiheelliseksi ehdottaa tästä päätehtävästä eräitä poikkeuksia. Tällaisia ovat taideaineiden opetus alle 16-vuotiaille, ammatillinen aikuiskoulutus ja tutkintotavoitteinen yleissivistävä koulutus. Tällainen opetus ei saisi toimikunnan mielestä kuitenkaan kaventaa opistojen muuta perinteistä toimintaa, joten se pitäisi resurssoida erikseen (s. 80). 
Kun olen seurannut erilaisissa olosuhteissa toimivia opistoja, olen vakuuttunut kaikkien näiden muutosten tarpeellisuudesta, vaikka ne merkitsevätkin opistojen alkuperäisen toiminta-ajatuksen hämärtymistä niin kuin esim. Urpo Harva on todennut (ks. Harva 1973) ${ }^{5}$. Vaihtoehtona on kuitenkin varsinkin maaseudulla se, että mikään taho ei järjestä opetusta näillä aloilla. Kansalaisopistojen roolin pitäisi näissä poikkeustapauksissa olla väistyvä eli jos jokin sopivampi organisoija voidaan löytää, tulee kansalaisopistojen luopua näiden tehtävien hoitamisesta.

\subsection{Organisaatio ja hallinto}

Saavumme nyt toimikunnan mietinnössä sellaisten asioiden pariin, jotka on käsitelty kahteen kertaan. Kohdasta 3.3. alkaen mietintöä aletaan ikään kuin kirjoittaa uudestaan. En ole aivan varma, kumpien muotoilujen takana toimikunta seisoo, sillä ne eivät kaikilta osiltaan ole yhtenevät. Oletan kuitenkin, että lähinnä se muotoilu, joka on otettu mukaan mietinnön tiivistelmään, on otettava vakavasti.

Toimikunta pitää hyvänä kansalaisopistojen nykyistä hallinnollista asemaa, joten se esittää, että toiminnan kehittämisen lähtökohtana on niiden nykyinen hallinnollinen asema (s. 80). Mutta toimikunnan mielestä on ollut ongelmiakin. Niitä on esiintynyt johtokunnan tehtävissä ja toimivaltuuksissa, koska niitä ei ole mainittu riittävällä tarkkuudella opistolaissa, vaan asetuksessa ja ohjesäännössä. Tästä on aiheutunut ristiriitaa kunnallislain kanssa. Toinen hankala asia on ollut johtokunnan asema kunnallisessa hierarkiassa. Kansalaisopistojen johtokunnan asema rinnastuu mieluummin esim. kirjastolautakuntaan kuin muiden oppilaitosten johtokuntiin. Niinpä toimikunta esittääkin, että johtokunta korvattaisiin kunnanvaltuuston toimikaudekseen valitsemalla kansalaisopistolautakunnalla, jonka tehtävät määritellään kansalaisopistojen valtionosuutta koskevassa laissa ja asetuksessa. Myös ohjesääntö korvattaisiin kunnanvaltuuston hyväksymällä opiston johtosäännöllä (s. 117-118).

Toimikunnan tarkoituksena on siis ollut vahvistaa opistojen itsenäistä hallinnollista asemaa. Pidän toimikunnan esityksiä periaatteessa oikean suuntaisina. Tietenkin nimitys kansalaisopistolautakunta kuulostaa kummal- liselta, mutta se on sittenkin pieni asia, jos näin voidaan lopettaa jatkuva kissanhännänveto opistojen suhteesta koululautakuntaan. Ja sitä parempi, mitä korkeamman asteisessa lainsäädännössä opistolautakunnan tehtävät lyödään lukkoon. Jos vertailukohtana pidetään kirjastolautakuntaa, toimikunnan ehdotus luopua ohjesäännöstä tuntuu yllättävältä, sillä sekin on toiminut eräänä takeena opistojen itsenäisyyden rajoituksia vastaan. Vaikka kirjastolautakunnan tehtävät luetellaan asetuksessa, on siellä tämän lisäksi edelleen käytössä läänin vahvistama ohjesääntö. Miksi siis opistojen pitäisi luopua ohjesäännöstä?

Tämän lisäksi mietintöön sisältyy ehdotus aluepohjaisten sivuosastojen ja ainepohjaisten sektoriosastojen perustamisesta (s. 81). Sitä voidaan pitää opistojen pedagogisen kehittämisen kannalta hyvänä.

Vaikka toimikunta ei analyysiosassaan puüttunut valtiollisen säätelyn kehitykseen, sisältyy toimenpide-ehdotusten joukkoon myös viittaus siihen, että toimikunta ei ole tyytyväinen kehityksen suuntaan. Toimikunta nimittäin ehdottaa, että valtion keskushallinnon rooli rajataan ensisijaisesti kansalaisopistojen toiminnalle edellytyksiä luovaksi ja opistojen valvonta ja ohjaus toteutuu läänin tasolla (s. 82). Siitä huolimatta, että toimikunnan ehdotus on ympäripyöreä (mitä tarkoittaa "toiminnalle edellytyksiä luova"'?), vastaa se kuitenkin KTOL:n edustajakokouksessa hyväksyttyä kantaa. Mielenkiintoista olisi ollut kuitenkin tietää, mitä tehtäviä toimikunta olisi halunnut siirtää kouluhallituksesta lääniin.

\subsection{Valtionosuusjärjestelmä}

Kaikkein sekavimmaksi toimikunnan esitys muuttuu käsiteltäessä valtionosuusjärjestelmän kehittämistä. Se on toimikunnan toimeksiannon tärkein yksittäinen asia. Ensinnäkin toimikunta esittää valtionosuusjärjestelmän kehittämisen kriteerit kahteen kertaan (s. 82-83 ja 125-126), eikä tietenkään samassa muodossa. Mutta vielä hankalampaa on se, että toimikunta ei osaa päättää, millaisen valtionosuusjärjestelmän se haluaisi opistoille. Jako kahteen tuntuu nyt suorastaan lipsumiselta.

Kommentoin ensin kuitenkin yleisesti sitä tapaa, jolla toimikunta lähestyy valtionosuusjärjestelmän kehittämistä. Opistojen saama valtionosuus rịppuu kolmesta tekijästä: valtionosuusperusteesta, valtionosuusprosentista 
ja toiminnan laajuudesta. Toimikunta ottaa laajemmin kantaa ainoastaan valtionosuusperusteeseen ja toiminnan laajuuteen (tuntikattojärjestelmä). Sen sijaan toimikunta ohittaa pelkällä maininnalla kysymyksen valtionosuusprosentin suuruudesta, vaikka viime kädessä juuri se on ratkaisevin opistojen kannalta. Toki toimikunta ehdottaa valtionosuusprosentin säilyttämistä 70 prosenttina (s. 128), mutta ehdotusta ei perustella sen tarkemmin. Tiedossa kuitenkin on, että vireillä on hankkeita (esim. kulttuuri- ja vapaa-aikatoimen valtionosuustyöryhmä), joiden nimenomaisena tarkoituksena on tasata kulttuuri- ja vapaaaikatoimen valtionosuusprosentit samoiksi. Tämähän tulisi merkitsemään opistojen valtionosuusprosentin roimaa pudotusta.

Näitä hankkeita perustellaan mahdollisimman latteasti sillä, että näin lisätään eri hallinnonalojen välistä tasa-arvoa ja annetaan kuntiin lisää valtaa päättää, mitä hallinnonalaa ne pitävät mielekkäimpänä kehittää. Juuri tähän velttoon eräiden byrokraattien ja poliitikkojen suosimaan tasa-arvohöpinään olisi toimikunnan pitänyt ottaa kantaa. Asia kun on yksinkertaisesti niin, että inhimillisen kulttuurin eri osa-alueet eivät kilpaile tasavertaisesti kansalaisten ja poliitikkojen suosiosta. Mitä enemmän harrastus vaatii, sitä vähemmän sillä on tukijoita. Silti näidenkin harrastusten toimintaedellytykset on turvattava, jos mielitään säilyä sivistyskansana. Ei opistojen nykyistä suosiota kansan keskuudessa selitä lisääntyvän vapaa-ajan ohella mikään muu kuin se, että harrastaminen ja opiskeleminen niissä on tällä hetkellä opiskelijoille halpaa ja että opistojen ylläpitäminen on kunnalle edullista. Kun nämä edellytykset otetaan pois, muuttuvat opistot hyväosaisten kohtaamispaikoiksi.

Jos toimikunta ohittaakin kysymyksen valtionosuusprosentista olan kohautuksella, niin tuntikattojärjestelmään sillä on selvä kanta. Toimikunta ehdottaa; että luovutaan sellaisista kaavamaisin arviointiperustein toteutettavista kansalais- ja työväenopistotoiminnan rajoituksista, jotka eivät ota huomioon opistokohtaisia olosuhteita (s. 85). Erityisen huolestunut toimikunta on tuntikattorajoituksen aiheuttamista vaikutuksista nuorille ja kasvaville opistoille. Tämä kanta vastaa opistoväen mielialoja. On selvää, että valtakunnan tasolla tuntikehitystä tullaan aina säätelemään, mutta mitään ehdotonta välttämättömyyttä nykyiseen jäykkään opistokohtaiseen säätelyyn ei ole olemassa. Asiat voitaisiin hoitaa joustavamminkin.
Pääsemme nyt vihdoin käsiksi siihen valtionosuusjärjestelmän osaan, joka on aiheuttanut eniten päänvaivaa toimikunnalle. Se toteaa ensin, että opistojen nykyinen valtionosuusjärjestelmä on peruspiirteissään toiminut hyvin. Ongelmana on lähinnä ollut valtionosuuksien viivästyminen sekä valtionavun tilitysten työläys. Nykyisen järjestelmän aikana valtio on kontrolloinut menojen kasvua säätelemällä opetustuntien määrää, rajoittamalla uusien päätoimisten virkojen perustamista sekä antamalla yksityiskohtaisia hallinnollisia määräyksiä (esim. hankinnoista) (s. 123). Näistä ongelmista huolimatta toimikunta esittää, että "mahdollisimman pikaisesti yksinkertaistetaan nykyistä menoperusteista valtionosuusjärjestelmää koskeva tilitysmenettely aikaavievine tarkastuksineen ja että tilittämättä olevat valtionosuuserät maksetaan viivytyksettä opiston ylläpitäjälle"' (s. 127).

Toimikunta ei kuitenkaan usko, että tämä myös KTOL:n edustajakokouksen kannattama vaihtoehto voisi toteutua, joten se tekee toisenkin ehdotuksen valtionosuusjärjestelmästä. Vaikka toimikunta itsekin pitää tätä ns. sekajärjestelmää huonompana vaihtoehtona, on juuri tämä vaihtoehto otettu mietinnön tiivistelmään ja lakiesityksen pohjaksi. Sekajärjestelmälle toimikunta esittää kaikkiaan kahdeksan vaatimusta (s. 127-128). Lyhyesti sanottuna sekajärjestelmässä osaan kustannuksista (rehtorin, opettajien ja luennoitsijoiden sekä opiskelijain matkoista aiheutuvat kustannukset, vuokrista ja vuokra-arvoista aiheutuvat kustannukset) saadaan todellisten menojen mukainen valtionosuus ja osaan (rehtorin ja opettajien palkat ja sosiaaliturvamaksut, muut 'käyttömenot eräin vähäisin poikkeuksin) laskennallinen valtionosuus, jonka perusteena olisi markkaa/opetustunti. Laskennallisen suoritteen osuus valtionosuudesta tulisi olemaan noin $80-90 \%$. Menoperusteisesti valtionosuutta saataisiin $10-20 \%$.

Sekajärjestelmän täydennykseksi toimikunta ehdottaa lisäavustusjärjestelmää, jonka avulla voitaisiin harkinnanvaraisesti avustaa erityisissä vaikeuksissa olevia opistoja. Lisäavustuksen saaminen riippuisi kuitenkin kulloisistakin suhdanteista ja päättäjien hyvästä tahdosta, joka viime vuosina on ollut ehtymään päin.

Käytännössä toimikunnan suosittelema sekajärjestelmä olisi siten hyvin lähellä puhdasta suoritejärjestelmää. Suoritejärjestelmää koh- 
taan on opistojen taholta esitetty paljon kritiikkiä, joka voidaan tiivistää seuraavasti:

- Opetustunti keskihintasuoritteena lisää paineita ryhmäkoon suurentamiseen ja sellaisten opetusjärjestelyjen käyttöönottamiseen, joissa tuntikustannukset ovat edullisimmat. Tämä ei läheskään aina vastaa pyrkimystä opetuksen laadun parantamiseen.

- Opetustunti valtakunnallisena keskiarvona asettaa huonoimpaan asemaan sellaiset opistot, joissa kustannukset alueellisten seikkojen vuoksi ovat suurimmat. Seurauksena on alueellisen eriarvoisuuden lisääntyminen.

Tämä kritiikki pätee myös toimikunnan ehdottamaan sekajärjestelmään, koska siinä menoperusteinen osuus jää niin vähäiseksi. Jos kehittelyä halutaan jatkaa sekajärjestelmän pohjalta, on lisättävä sen herkkyyttä reagoida opistokohtaisiin eroihin. Nythän opistojen tuntikohtaiset menot saattavat vaihdella vajaasta 100 markasta yli 250 markkaan.

Yhteenvetona toimikunnan ehdotuksista valtionosuusjärjestelmän kehittämiseksi totean, että niistä ei ole muuhun kuin jatkovalmistelun pohjaksi.

Lisäksi toimikunta tekee koko joukon esityksiä, joilla on merkitystä käytännön opistotyön kannalta. Jätän ne kuitenkin tässä yhteydessä kommentoimatta tilan puutteen vuoksi.

\subsection{Lainsäädäntö}

Toimikunnan toimeksiantoon kuului myös tehdä ehdotus lainsäädännöllisiksi muutoksiksi. Näin toimikunta on menetellytkin. Tosin aika ei ole riittänyt kuin lakiehdotuksen tekstin sorvaamiseen. Asetusta varten on vain lueteltu joukko "tekijöitä", jotka asetusta kirjoitettaessa tulisi ottaa huomioon.

Laki tulisi edelleen olemaan valtionosuuslaki niin kuin nykyinenkin. Ensimmäisessä pykälässä määritellään opistojen tarkoitus. Vaikka toimikunnalla olikin jo valmis määrittely opistojen luonteesta (s. 78), niin se ei ole kelvannut enää lakitekstiin - valitettavasti. Lakitekstin ehdotus on nimittäin olennaisesti sekavampi ja heikommin muotoiltu. Ehdotuksen mukaan "'kansalais- ja työväenopistoilla tarkoitetaan tässä laissa aikuisoppilaitosta, jonka tehtävänä on tyydyttää kansalaisten sivistystarpeita, edistää aikuisten omaehtoista henkistä kehittymistä ja antaa mahdollisuuden hankkia ja ylläpitää lähinnä heidän vapaa-aikoinaan sellaisia tietoja ja taitoja, jotka ovat tarpeellisia kansalaiselämässä, täydentävät yleis- sivistävää pohjakoulutusta sekä edistävät jatko- ja itseopiskelua" (s. 130-131).

Ehdotuksessa rinnastuvat onnettomasti mitä erilaisimmat käsitteet (niin kuin sivumennen sanoen nykyisessäkin valtionosuuslaissa). Tämä jää parhaimmillaan pelkäksi semanttiseksi sekamelskaksi, mutta pahimmillaan se voi aiheuttaa kiperiä tulkintaongelmia. Uusi muotoilu on siten tarpeen.

Itse valtionosuuden määräytymistä koskevat pykälät on kirjoitettu edellä kuvatun sekajärjestelmän pohjalta. Aikaisemmin esittämäni kritiikin perusteella pidän hyvänä ainoastaan ehdotusta valtionosuusprosentin säilyttämisestä $70 \%$ :na ja pykälään viisi sisältyviä ehdotuksia eräistä valtionosuuden myöntämisen edellytyksistä (taideaineiden opetus alle 16vuotiaille, ei ryhmäkokosäännöksiä). Muuten koko valtionosuuskohta pitäisi valmistella uudestaan.

Lakiesitykseen sisältyy myös ehdotus opistolautakunnasta ja sen yleisistä tehtävistä. Muodollisesti en pidä hyvänä, että opistolautakunnan tehtävistä määrätään sekä laissa että asetuksessa, vaikka ymmärrän hyvin toimikunnan päätyneen tähän ratkaisuun. On haluttu varmistaa lautakunnan aseman horjumattomuus.

Lakiesityksen kahdeksanteen pykälään sisältyy pieni, mutta sitäkin tärkeämpi muutos nykyiseen lakiin verrattuna. Ehdotuksen mukaan valtionavustukseen ja korkotukilainaan oikeuttaviksi perustamiskustannuksiksi hyväksyttäisiin tulevaisuudessa myös kiinteän omaisuuden, määräalan tai rakennuksen hankkimisesta aiheutuvat kustannukset. Tähän astihan perustamiskustannuksiksi on hyväksytty vain rakentamisesta ja korjaamisesta aiheutuvat kustannukset. Tämä on tärkeä uudistus, mikäli se toteutuu.

Muuten lakiesitys noudattelee keskeisiltä osiltaan nykyistä lakia. Koska lakiesityksen pohjana oleva valmistelutyö on jäänyt tärkeimmiltä osiltaan (valtionosuus) pahasti keskeneräiseksi, olen sitä mieltä, että se on kirjoitettava vielä kokonaan uudestaan.

\section{Kysymys aikuisopistosta}

Pohtiessaan kuntatason aikuiskoulutuksen organisaatiota ja hallintoa toimikunta esittää idean eri aikuiskoulutusmuotojen yhdistämisestä yhdeksi, aikuiskoulutuslautakunnan alaisuudessa toimivaksi aikuisopistoksi. Tämä olisi pitkän tähtäimen asia. Näiltä osin toimikunta ei tehnyt varsinaisia esityksiä (s. 110). 
Uskon, että tämä olisi byrokratian toiveuni. Kaikki tällä hetkellä sietämättömän erilaiset aikuiskoulutuksen muodot saataisiin yhteen karsinaan. Kuinka yksinkertaista niiden hallitseminen tulisikaan olemaan. Luultavasti voitaisiin ennen pitkää osoittaa, miten tarpeetonta on ylipäätään korostaa eri aikuiskoulutusmuotojen toisistaan poikkeavia perinteitä ja toimintatapoja. Päästäisiin vähitellen siihen, että olisi vain "kunnallista aikuiskoulutusta", jon$\mathrm{ka}$ sisältä löytyisi erilaisia suuntautumisvaihtoehtoja. Kaikki olisi niin yksinkertaista ja kokonaisvaltaista.

Jotenkin omituiselta tuntuu lukea tällaisia ajatuksia mietinnöstä, jota on ollut valmistelemassa myös vapaan sivistystyön edustajia. Ehkä sittenkin pitää paikkansa, että myös vapaaseen sivistystyöhön on syntynyt katkos sivistyspersoonien katoamisen myötä. Kun muilla koulutuksen sektoreilla yritetään epätoivoisesti päästä pois loputtomasta keskittämisestä, niin eikö vain ilmestykin idea aikuisopistosta, joka väistämättä tulisi tuhoamaan nykyisten aikuiskoulutusmuotojen omaleimaisuuden ja joustavuuden. Toivottavasti idea aikuisopistosta tulee myös jäämään ideaksi.

\section{Viitteet}

1. Sihvonen, J., Vapaasta sivistystyöstä kunnalliseen aikuiskoulutukseen. Aikuiskasvatus 1/82

2. Käytettävissäni on ollut vain monistettu kopio mietinnöstä, joten viittaukset sivunumeroihin eivät tule mahdollisesti pitämään paikkaansa painetun mietinnön kanssa.

\section{Lopuksi}

Kun aikuiskoulutuskomitean mietintö valmistui, alkoi vähitellen vapaan sivistystyön kentältä kuulua kiihtyvää kritiikkiä komitean esityksiä kohtaan. Varsinkin kritikoitiin sitä, että komitea sorti vapaata sivistystyötä ammatillisen aikuiskoulutuksen kustannuksella. Esitettiin myös ajatus siitä, että komitea oli käsitevalinnoillaan häivyttämässä vapaan sivistystyön ominaislaadun. Kunnallisen aikuiskoulutuksen toimikunnan työskentelyyn kohdistui siten suuria ennakko-odotuksia, tarjosihan se mahdollisuuden perustella vapaan sivistystyön tarpeellisuutta. Yllä olevan nojalla ei enää ole epäselvää, että olen melkoisen pettynyt toimikunnan aikaansaannoksiin. Pidän sitä koulutussuunnittelun kannalta taka-askeleena, vaikka moniin sen ehdotuksista voikin yhtyä. Ei ole eduksi vapaalle sivistystyölle, että kiireellistä korjausta kaipaavat ongelmat perustellaan niin sekavasti kuin mietinnössä on tehty. Täytyy ainoastaan toivoa, että siitä ei tule estettä korjauksien toteuttamiselle.

3. Alanen, A., Aikuiskasvattajan ammatti: kehityssuuntia ja ongelmia. Vapaan sivistystyön XXIV vuosikirja. Juva 1980 , s. $29-63$.

4. Harva, U., Tasa-arvo ja kasvatus. Aikuiskasvatus $4 / 82$.

5. Harva, U., Suomalainen aikuiskasvatus. Helsinki 1973. 